\title{
Follicular dendritic cell sarcoma: two rare cases and a brief review of the literature
}

This article was published in the following Dove Press journal:

OncoTargets and Therapy

24 July 2015

Number of times this article has been viewed

Yuan Ma',*
Jujie Sunn,*
Cuicui Yang'
Dandan Yuan
Jie Liu

'Department of Oncology, Shandong Cancer Hospital \& Institute, School of Medicine and Life Sciences, University of Jinan-Shandong Academy of Medical Sciences, Shandong Province, People's Republic of China; ${ }^{2}$ Department of Pathology, ${ }^{3}$ Department of Oncology, Shandong Cancer Hospital \& Institute, Jinan, Shandong Province, People's Republic of China

*These authors contributed equally to this work
Correspondence: Jie Liu

Department of Oncology, Shandong Cancer Hospital, No 440 Jiyan Road, Huaiyin District, Jinan, Shandong Province 250I 17, People's Republic of China

Tel +8653 I 67626332

Fax +8653 I 87984079

Email liujiesdch@I26.com

\begin{abstract}
Follicular dendritic cell sarcoma (FDCS) is a rare malignant tumor recognized in recent years. It accounts for only $0.4 \%$ of soft-tissue sarcomas, and its underlying causes are largely unknown. A correct diagnosis can be difficult to make. Diagnosis of FDCS depends on the combined clinical examination, histopathologic features, electron microscopic examination and confirmation with immunohistochemical studies. Here, we report two rare cases of FDCS: one case involving multiple bones, and the other involving extensive abdominal and pelvic cavities. Clinical, histopathological, and immunohistochemical aspects, therapeutic options, and a related literature review of the two cases are discussed. As the prevalence of FDCS is increasing, the details of these rare cases may highlight the importance and facilitate treatment of similar diseases.
\end{abstract}

Keywords: FDCS, bone, abdominal cavity, pelvic cavity, diagnosis, therapy

\section{Introduction}

Classified as accessory cells of the immune system, the follicular dendritic cells (FDCs), also known as dendritic reticulum cells, are essential for the humoral response by providing antigen presentation and B-cell response maturation. FDCs are located primarily in the germinal centers of primary and secondary lymphoid follicles of nodal and extranodal sites. ${ }^{1}$ Lymphoid follicles are found in the lymph nodes and in extranodal lymphoid tissue. ${ }^{2}$

Follicular dendritic cell sarcoma (FDCS), also known as dendritic reticulum cell sarcoma, is a neoplasm of reticular dendritic origin. Monda et $\mathrm{al}^{3}$ first described this entity in 1986 based on a series of four cases, all of which occurred in lymph nodes. Since then, only a few cases have been reported in the literature. In most of these cases, the major sites affected are the lymph nodes, ${ }^{4-6}$ and extranodal sites are involved in almost one-third of the patients. ${ }^{7}$ Because of the low incidence and limited experience of the disease, FDCS is often not considered at the initial evaluation and may be misdiagnosed. Here, we present two rare cases of FDCS: one case involving multiple bones and the other involving extensive abdominal and pelvic cavitities. Upon review of the literature, we identified only two additional cases of FDCS involving bone and four cases involving extensive abdominal and pelvic cavities. Given the rarity of bone or extensive abdominal and pelvic cavity involvement by FDCS and the lack of consensus on treatment, evaluation of this entity must continue.

\section{Case series Case I}

In June 2005, a 24-year-old man presented with intermittent pain in multiple bones such as the thorax, lumbar vertebra, and ribs for 2 months. There was no significant past 
medical history. Computed tomography (CT) scan revealed multiple enlarged lymph nodes in the bilateral axillary and supraclavicular area, and the diameter of the largest one was about $2.1 \mathrm{~cm}$. A subsequent bone scan was acquired and demonstrated high levels of radioactivity accumulation in multiple bones, such as the spine, ribs, shoulder blade, and others (Figure 1). Abdominal ultrasound scan revealed no abnormalities. Routine biochemical and hematological tests were within normal limits. The patient underwent incision biopsy of the left cervical lymph node. Based on the histopathological and clinical manifestation, the patient was diagnosed with FDCS.

Because of the tumor's unfavorable location and multiple site involvement, surgical therapy was not performed. The patient received four cycles of chemotherapy consisting of etoposide plus cisplatin. To evaluate the efficacy of the therapy, a CT scan was performed, which revealed that the swollen lymph nodes disappeared completely. His symptoms improved immediately. To consolidate and strengthen treatment, an additional six cycles of chemotherapy with a standard dose of cyclophosphamide, doxorubicin, vincristine, and prednisone (CHOP) were performed. This regimen was completed in December 2006. The patient was followed up every 6 months. Up until now, there is no evidence of recurrence.

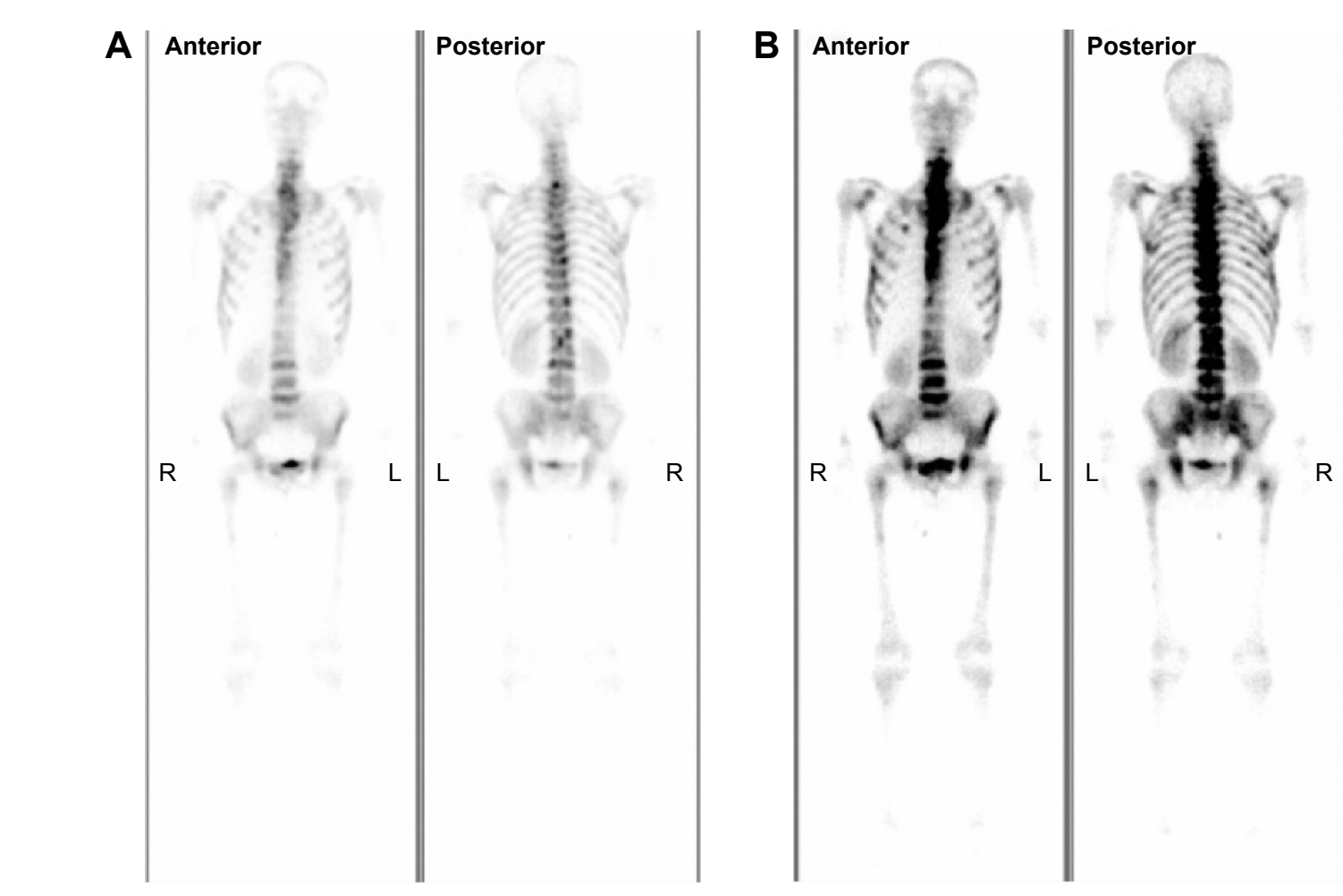

\section{Case 2}

In case 2, a 24-year-old woman had presented with 65 days of delayed menstruation and a 2-month history of lower abdominal fullness, initially. She had a poor appetite and had lost $2 \mathrm{~kg}$ in weight. No abdomen ache, diarrhea, or melena was noted. Her physical exam demonstrated a hard, ill-defined, and tender mass in the upper abdominal region and shifting dullness was positive. CT showed lumps of varying sizes in the pelvic and abdominal cavity. Massive ascites and pelvic fluids were found (Figure 2). No enlarged lymph nodes could be seen in the whole body. Carcinoembryonic antigen and CA19-9 levels were normal. The CA125 level was slightly increased. The patient was diagnosed with ovarian cancer with abdominal and pelvic cavity metastasis initially and received cytoreductive surgery. Macroscopic surgical exploration revealed an encapsulated nodular mass measuring $15 \times 15 \times 10 \mathrm{~cm}$ at the lesser curvature of the stomach, and other tumor nodules were dotted around the ovary, anterior wall of the uterus, mesentery, omentum, and liver capsule. Multiple sections were taken from all tumor nodules. An excisional biopsy was performed to confirm the diagnosis and the pathologic findings were consistent with FDCS. Based on the histopathological and immunohistochemical findings, the

Figure I The whole-body bone imaging of case I.

Note: Imaging demonstrated high levels of radioactivity accumulation in multiple bones, such as the sternum, spine, ribs, shoulder blade, and others. The first set of images (A) mainly showed sternum, spine, and pelvis metastases. The second set of images (B) mainly showed shoulder blades, ribs and femur metastases.

Abbreviations: L, left; R, right. 

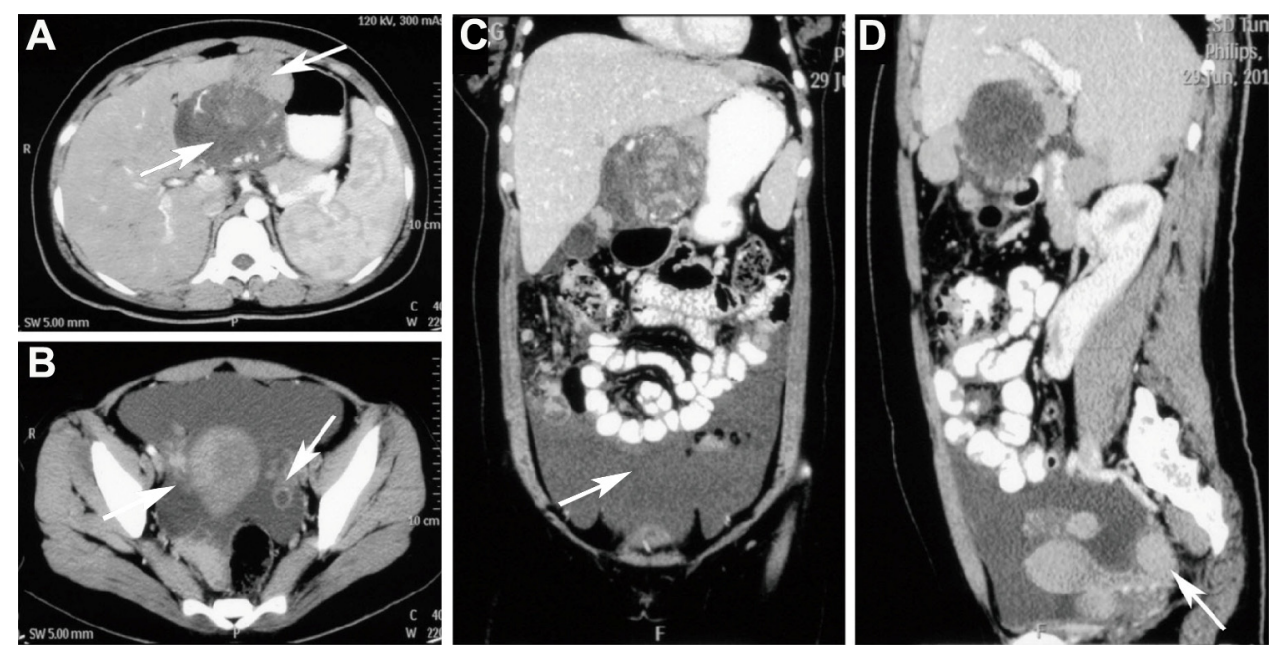

Figure 2 Computed tomography images of case 2.

Notes: (A) Located in gastric omental bursa, low attenuation mass (arrow) showed heterogeneous enhancement on arterial phase CT. Nodular thickening of the liver capsule could be seen (arrow). (B) CT image of the pelvic cavity showed cystic-solid mixed masses (arrow) in bilateral annex area. (C) Coronal postcontrast CT scan showed a large amount of fluid (arrow) in the abdominal and pelvic cavity. (D) Sagittal postcontrast CT scan showed multiple nodules (arrow) in the pelvic peritoneum area.

Abbreviation: CT, computed tomography.

patient was diagnosed with FDCS of extensive abdominal and pelvic cavity involvement.

She received postoperative sequential chemotherapy. Four cycles of CHOP were initiated in July 2012. After three courses of chemotherapy, a subsequent CT scan was performed, which showed the patient's disease had improved significantly. Two months later, CT revealed the disease had progressed and the regimen was changed to six cycles consisting of ICE (ifosfamid, carboplatin, and etoposide). This regimen was completed in July 2013. When a subsequent positron emission tomographic scan revealed persistent disease, the patient received enterolysis and cytoreductive surgery. After operation, she elected not to receive adjuvant therapy. Unfortunately, her disease could not be controlled and she died 5 months later.

\section{Materials and methods}

Pathological materials were taken for routine histologic processing with formalin fixation and paraffin embedding. Sections $(4 \mu \mathrm{m})$ cut from the tissue blocks were stained with hematoxylin and eosin and used for immunohistochemical staining. Immunohistochemical staining was performed using the EnVision method. The panel of antibodies included antibodies against CD21, CD35, CD23, vimentin, CD20, CD30, CD117, S-100, CD68, CD45, epithelial membrane antigen (EMA), D2-40, and Epstein-Barr virus-encoded RNA (EBER). Antibodies were offered by Beijing Zhongshan Golden Bridge Biotechnology Co., Ltd. (Beijing, People's Republic of China). The manufacturer's instructions were followed with no modifications. Primary antibodies were replaced by phosphate-buffered saline as a negative control.

\section{Pathologic results Case I}

Microscopic examination showed that lymph structure was replaced by the tumor cells arranged in a wispy and storiform pattern. These tumor cells had mild eosinophilic cytoplasm with clear cell borders and the nuclei were small. Small lymphocytes were scattered throughout the tumor cells (Figure 3A). The tumor cells exhibited positive immunohistochemical staining for CD21 and CD35 as well as negative staining for CD23, vimentin, CD20, CD30, CD117, EMA, S-100, CD45, CD68, D2-40, and EBER (Figure 3).

\section{Case 2}

Microscopic examination revealed that the lesser curvature of the stomach tumor was composed of oval and long spindle cells that were arranged in bundles. These tumor cells had mild eosinophilic cytoplasm with distinct cell borders and chromatin that were in the shape of physalides (Figure 4A). Immunoperoxidase staining showed tumor cells to be reactive with CD21, CD35, CD23, vimentin, CD30, and EMA. There was no reactivity with antibodies to CD20, CD68, S-100, CD117, D2-40, CD45, or EBER (Figure 4). Tumor cells of the same origin were found at the ovary, uterus, and other sites. 

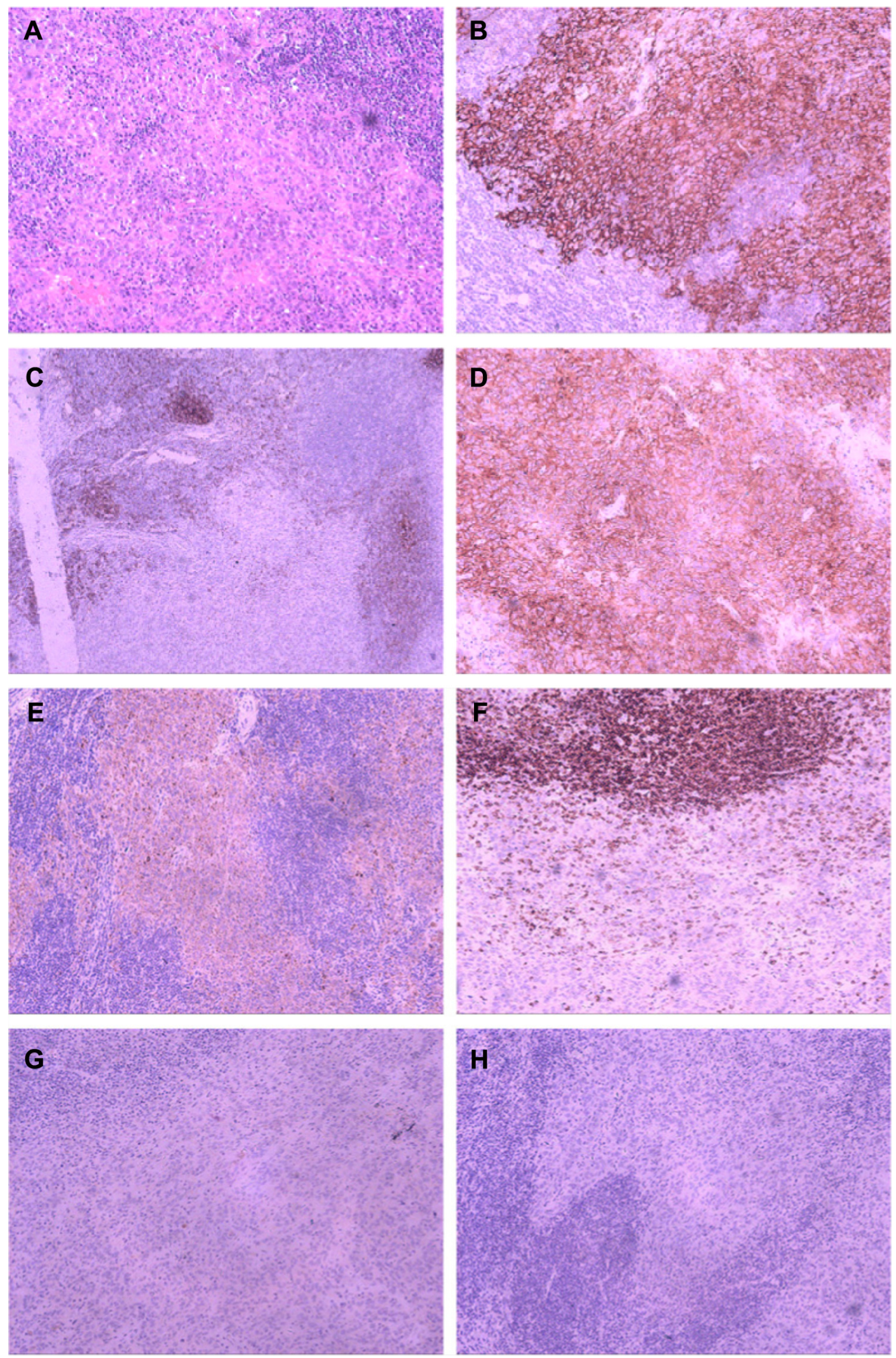

Figure 3 Tumor histology of case I.

Notes: (A) The histopathological appearance indicated that the tumor was composed of cells arranged in a wispy and storiform pattern and that these cells were admixed with lymphocytes (hematoxylin and eosin stain, $\times 200)$. (B) Positive for CD2I staining $(\times 200)$. (C) Negative for CD23 staining $(\times 200)$. (D) Positive for CD35 staining $(\times 200)$. (E) Negative for CD68 staining $(\times 200)$. (F) Negative for CD45 staining $(\times 200)$. (G) Negative for D2-40 staining $(\times 200)$. (H) Negative for EBER staining $(\times 200)$. Abbreviation: EBER, Epstein-Barr virus-encoded RNA. 

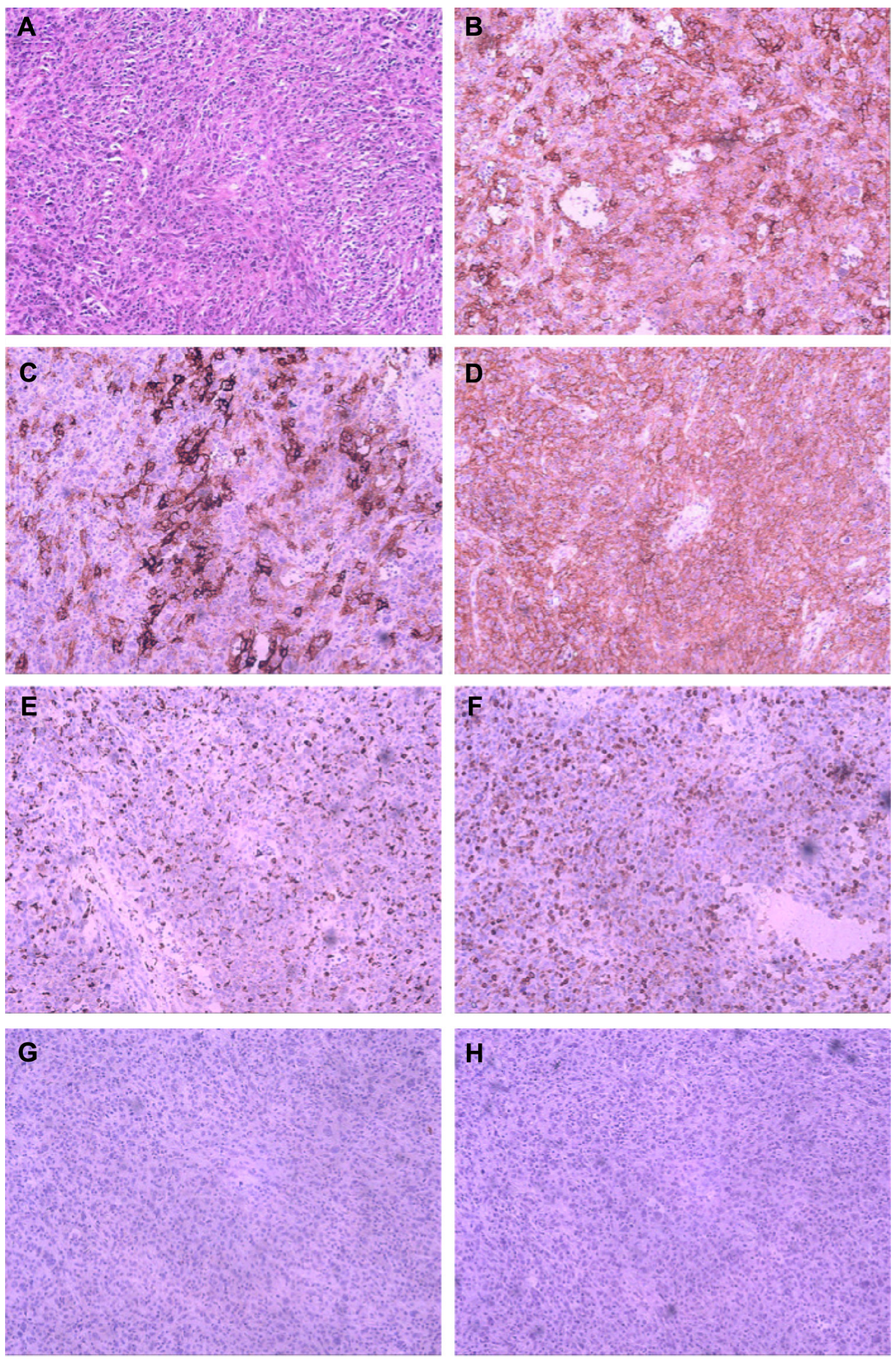

Figure 4 Tumor histology of case 2.

Notes: (A) Section demonstrated oval and long spindle cells arranged in bundles (hematoxylin and eosin stain, $\times 200)$. (B) Positive immunohistochemical staining for CD2 I

( $\times 200)$. (C) Positive immunohistochemical staining for CD23 $(\times 200)$. (D) Positive immunohistochemical staining for CD35 $(\times 200)$. (E) Negative for CD68 staining $(\times 200)$. (F) Negative for CD45 staining $(\times 200)$. (G) Negative for D2-40 staining $(\times 200)$. (H) Negative for EBER staining $(\times 200)$.

Abbreviation: EBER, Epstein-Barr virus-encoded RNA. 


\section{Discussion}

FDCS usually occurs in lymph nodes, especially in the cervical, mediastinal, and axillary areas, but it can occur in extranodal sites such as in the liver, lungs, tonsils, or spleen. ${ }^{8}$ It is a rare tumor that presents in a wide range of ages. FDCS generally affects young to middle-aged adults, without sex predilection. ${ }^{4}$ Both cases in our report were only 24 years old. The causes of FDCS are largely unknown. Associations with Castleman disease ${ }^{9}$ have been reported. The EpsteinBarr virus is suspected to carry a viral oncogene that might encourage transformation. ${ }^{10}$

Pathological diagnosis is essential for FDCS. FDCS may be suspected if the tumor exhibits distinct microscopic features, such as a storiform arrangement of spindle-shaped cells and a background of lymphocytes scattered throughout the neoplastic cells. ${ }^{11}$ The morphologies of our cases are typical of FDCS. To confirm the tumor, immunohistochemical staining is also required. The most widely used FDC markers, including CD21, CD35, and CD23, can be used for confirmation. Other markers including vimentin, CD68, CD45, CD3, CD20, EMA, melanoma (HMB-45), and Ki-67 (MIB-1) can be variably positive, although they lack specificity. The S-100 and certain vascular or muscular markers may also help to distinguish this tumor from other tumors, such as malignant peripheral nerve sheath tumors and gastrointestinal stromal tumors. ${ }^{12}$ The diagnosis of an FDC tumor is established based on the findings of morphology and immunohistochemistry. Ultrastructural studies may be helpful but are not indispensable for accurate diagnosis. The most distinctive feature is numerous long, slender, interwoven cytoplasmic processes joined by well-formed desmosomes. ${ }^{13}$

The optimal treatment for FDCS is yet to be found, owing to limited experience. A complete surgical excision is the appropriate initial therapy. ${ }^{2}$ The role of adjuvant therapy (radiotherapy or chemotherapy) remains unclear because of the rarity of the disease. Adjuvant therapy appears to be indicated in cases of incompletely resected lesions or adverse pathological features during recurrence. ${ }^{14}$ Because curative surgery was not possible for the patient with multiple bone metastases, we opted for chemotherapy for case 1 . As for the second patient, we chose chemotherapy combined with cytoreductive surgery. Both patients were given CHOP regimen. This regimen was widely used and showed its efficacy in our study. Other chemotherapeutic agents such as ABVD (adriamycin, bleomycin, vinblastine, dacarbazine), EPOCH (etoposide, prednisolone, oncovin, cyclophosphamide, hydroxydaunorubicin), ICE, and cisplatin/epirubicin have also been proposed with inconsistent results. ${ }^{15}$ Imatinib in combination with gemcitabine and cisplatin ${ }^{16}$ and rituximab ${ }^{17}$ was also reported to have some activity against FDCS.

FDCS is considered as an intermediate-grade malignancy. Chan et al ${ }^{4}$ analyzed the clinicopathologic features of 17 cases of FDCS and found that the overall recurrence, metastasis, and mortality rates were $43 \%, 24 \%$, and $17 \%$, respectively. To the best of our knowledge, only two well-documented cases of FDCS of bone involvement have been reported in the English literature (Table 1). In one patient, originating in the mediastinum, the tumor metastasized to the pelvic bone and involved the bone marrow after 18 months. The patient received chemotherapy and lived with the tumor in the follow-up 2 years. The other patient with multiple bone metastases received 12 cycles of chemotherapy. In a follow-up 2 years after the initial diagnosis, the patient's disease was rated as stable. There was no significant correlation of the clinical outcome with histological features. Our patient (Case 1) presented with bone metastasis, and his disease was stable in the follow-up 9 years after appropriate therapy. Although there are a limited number of cases, we can conclude that FDCS involving bone shows slow progress after correct chemotherapy.

Table I Summary of three cases of FDCS involving bone

\begin{tabular}{|c|c|c|c|c|c|c|}
\hline Case/ref no & $\begin{array}{l}\text { Age } \\
\text { (years) }\end{array}$ & Sex & Site of tumor & Treatment & Outcome & Immunophenotype \\
\hline $1^{18}$ & 45 & $F$ & $\begin{array}{l}\text { Mediastinal, bone marrow } \\
\text { involvement }\end{array}$ & Chemotherapy & $\begin{array}{l}\text { Alive with tumor } \\
\text { in a follow-up } 2 \\
\text { years }\end{array}$ & 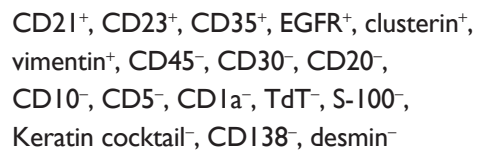 \\
\hline $2^{19}$ & 36 & $\mathrm{~F}$ & $\begin{array}{l}\text { Lymph node in the left } \\
\text { hilum of the lung, multiple } \\
\text { bone metastases }\end{array}$ & Chemotherapy & $\begin{array}{l}\text { Stable in a } \\
\text { follow-up } 2 \text { years }\end{array}$ & $\begin{array}{l}\mathrm{CD} 35^{+}, \mathrm{CD} 2 \mathrm{I}^{-}, \mathrm{CD} 68^{+}, \mathrm{CD} 163^{+} \\
\mathrm{S}-100^{+}, \mathrm{Ki}^{-} 67^{+}, \mathrm{LYSO}^{+}, \mathrm{LCA}^{+}, \mathrm{CD} \mathrm{Ia} \\
\mathrm{CD} 44^{-}, \mathrm{CD} 2 \mathrm{I}^{-}, \mathrm{CD} 56^{-}\end{array}$ \\
\hline 3 (case I) & 24 & M & $\begin{array}{l}\text { Multiple enlarged lymph } \\
\text { nodes in the bilateral } \\
\text { axillary, supraclavicular area, } \\
\text { multiple bone metastases }\end{array}$ & Chemotherapy & $\begin{array}{l}\text { Stable in a } \\
\text { follow-up } 9 \text { years }\end{array}$ & $\begin{array}{l}\mathrm{CD} 2 \mathrm{I}^{+}, \mathrm{CD} 35^{+} \text {, vimentin }{ }^{+}, \mathrm{D} 2-40^{+} \text {, } \\
\text { cytokeratin }{ }^{-}, \mathrm{CD} 20^{-}, \mathrm{CD} 30^{-}, \mathrm{CD} \mathrm{I} 7^{-} \text {, } \\
\text { epithelial membrane antigen }{ }^{-}, \mathrm{S}-100^{-}\end{array}$ \\
\hline
\end{tabular}

Abbreviations: Ref no, reference number; F, female; FDCS, follicular dendritic cell sarcoma; M, male. 
Table 2 Summary of five cases of FDCS involving extensive abdominal and pelvic cavities

\begin{tabular}{|c|c|c|c|c|c|c|c|}
\hline Case/ref no & $\begin{array}{l}\text { Age } \\
\text { (years) }\end{array}$ & Sex & Initial symptoms & Site of tumor & Immunophenotype & Treatment & Outcome \\
\hline $1^{20}$ & 48 & $\mathrm{~F}$ & $\begin{array}{l}\text { Fatigue, abdominal } \\
\text { distension for } 3 \text { months }\end{array}$ & $\begin{array}{l}\text { Extensive pelvic and } \\
\text { abdominal cavity } \\
\text { involvement }\end{array}$ & $\begin{array}{l}\mathrm{CD}^{2} 5^{+}, \mathrm{CD}_{2} \mathrm{I}^{+}, \mathrm{EGFR}^{+}, \\
\mathrm{CD} 34^{-}, \mathrm{LCA}^{-}, \mathrm{S}-100^{-} \\
\mathrm{CDII}^{-}, \text {Calponin }^{-}\end{array}$ & $\begin{array}{l}\text { Operation, } \\
\text { chemotherapy }\end{array}$ & $\begin{array}{l}\text { Recurrence } \\
\text { after } 2 \text { years }\end{array}$ \\
\hline $2^{21}$ & 33 & $\mathrm{~F}$ & $\begin{array}{l}\text { 2-month history of } \\
\text { lower abdominal fullness }\end{array}$ & $\begin{array}{l}\text { Extensive peritoneal } \\
\text { involvement }\end{array}$ & $\begin{array}{l}\mathrm{CD} 2 \mathrm{I}^{+}, \mathrm{CD} 35^{+} \\
\mathrm{Ki}-67^{+}>50 \%\end{array}$ & $\begin{array}{l}\text { Not } \\
\text { mentioned }\end{array}$ & $\begin{array}{l}\text { Not } \\
\text { mentioned }\end{array}$ \\
\hline $3^{22}$ & 70 & $M$ & $\begin{array}{l}\text { Lower abdominal } \\
\text { colic pain of } 2 \text { weeks' } \\
\text { duration }\end{array}$ & $\begin{array}{l}\text { Involving liver, spleen, } \\
\text { lesser omentum, } \\
\text { gastrosplenic ligament, } \\
\text { and peripancreatic region }\end{array}$ & $\begin{array}{l}\mathrm{CD}_{2} \mathrm{I}^{+}, \mathrm{CD} 35^{+}, \mathrm{CD} \mathrm{a}^{-}, \\
\mathrm{CD}^{-}, \mathrm{CD} 20^{-}, \mathrm{CD}^{-} 3^{-} \\
\mathrm{CD}^{\prime} 8^{-}, \mathrm{S}-100^{-}\end{array}$ & $\begin{array}{l}\text { Not } \\
\text { mentioned }\end{array}$ & $\begin{array}{l}\text { Not } \\
\text { mentioned }\end{array}$ \\
\hline $4^{23}$ & 44 & $\mathrm{~F}$ & $\begin{array}{l}\text { Intermittent } \\
\text { constipation }\end{array}$ & $\begin{array}{l}\text { Involving peripancreatic } \\
\text { and subhepatic region }\end{array}$ & $\begin{array}{l}\mathrm{CD}^{2} 3^{+}, \mathrm{CD}^{-} \mathrm{O}^{-}, \mathrm{S}-\mathrm{I00}^{-} \text {, } \\
\mathrm{CDIa}^{-}, \mathrm{ALK}^{-}\end{array}$ & $\begin{array}{l}\text { Partial resection } \\
\text { followed by } \\
\text { chemotherapy }\end{array}$ & $\begin{array}{l}\text { Disease free } \\
\text { at } 29 \text { months }\end{array}$ \\
\hline 5 (case 2 ) & 24 & $\mathrm{~F}$ & $\begin{array}{l}\text { Abdominal distension } \\
\text { for } 2 \text { months }\end{array}$ & $\begin{array}{l}\text { Extensive pelvic and } \\
\text { abdominal cavity } \\
\text { involvement }\end{array}$ & $\begin{array}{l}\mathrm{CD} 2 \mathrm{I}^{+}, \mathrm{CD} 35^{+}, \text {vimentin } \\
\mathrm{CD} 23^{+}, \mathrm{CD} 30^{+}, \mathrm{EMA}^{+}, \\
\mathrm{CD} 34^{-}, \mathrm{CD} 3^{-}, \mathrm{CD} 20^{-}, \\
\mathrm{CD} 68^{-}, \mathrm{S}-100^{-}, \mathrm{CD} 1 \mathrm{I7}^{-}\end{array}$ & $\begin{array}{l}\text { Chemotherapy, } \\
\text { operation }\end{array}$ & $\begin{array}{l}\text { Died after } \\
5 \text { months }\end{array}$ \\
\hline
\end{tabular}

Abbreviations: Ref no, reference number; F, female; FDCS, follicular dendritic cell sarcoma; M, male.

Extensive abdominal or pelvic involvement by FDCS was unusual. We identified five similar reports in the literature and the present case adds to this total (Table 2). The age of patients at diagnosis ranged from 24 to 70 years (mean, 43.8 years). The common feature of these cases is that the multiple organ metastasis occurred at first and pursued an aggressive and rapid course. Some studies show that those with unfavorable prognostic factors, such as coagulative necrosis, high mitotic count ( $\geq 5$ per 10 high-power fields), significant cellular atypia or a tumor diameter of greater than $6 \mathrm{~cm}$, or intra-abdominal involvement, pursued a rapidly fatal clinical course. ${ }^{4,24}$ In case 2, we also demonstrated a trend toward higher recurrence and worse prognosis. Thus, intra-abdominal or pelvic cavity FDCS may have a higher degree of malignancy than we recognize and should be worthy of more attention.

\section{Conclusion}

FDCS is a rare entity and has been recognized with increasing frequency. The diagnosis must be kept in mind when confronted with uncommon histological features in lymphoid tissue. Complete surgical excision is currently the best method to treat early-stage FDCS. Even though no consensus on adjuvant therapy has been developed, chemotherapy may be a good option in patients with advanced unresectable disease and could extend the survival of a patient with FDCS to a certain extent. Pathogenesis and therapy of FDCS needs further investigation.

\section{Disclosure}

The authors report no conflicts of interest in this work.

\section{References}

1. van Nierop K, de Groot C. Human follicular dendritic cells: function, origin and development. Semin Immunol. 2002;14(4):251-257.

2. Karabulut B, Orhan KS, Guldiken Y, et al. Follicular dendritic cell sarcoma of the nasopharynx. Int J Oral Maxillofac Surg. 2012;41(2): 218-220.

3. Monda L, Warnke R, Rosai J. A primary lymph node malignancy with features suggestive of dendritic reticulum cell differentiation. A report of 4 cases. Am J Pathol. 1986;122(3):562.

4. Chan JK, Fletcher CD, Nayler SJ, et al. Follicular dendritic cell sarcoma. Clinicopathologic analysis of 17 cases suggesting a malignant potential higher than currently recognized. Cancer. 1997;79(2):294-313.

5. Grogg KL, Lae ME, Kurtin PJ, et al. Clusterin expression distinguishes follicular dendritic cell tumors from other dendritic cell neoplasms: report of a novel follicular dendritic cell marker and clinicopathologic data on 12 additional follicular dendritic cell tumors and 6 additional interdigitating dendritic cell tumors. Am J Surg Pathol. 2004;28(8):988-998.

6. Cheuk W, Chan JKC, Shek TWH, et al. Inflammatory pseudotumor-like follicular dendritic cell tumor: a distinctive low-grade malignant intraabdominal neoplasm with consistent Epstein-Barr virus association. Am J Surg Pathol. 2001;25(6):721-731.

7. Youens KE, Waugh MS. Extranodal follicular dendritic cell sarcoma. Arch Pathol Lab Med. 2008;132(10):1683-1687.

8. Saygin C, Uzunaslan D, Ozguroglu M, et al. Dendritic cell sarcoma: a pooled analysis including 462 cases with presentation of our case series. Crit Rev Oncol Hematol. 2013;88(2):253-271.

9. Shinagare AB, Ramaiya NH, Jagannathan JP, et al. Primary follicular dendritic cell sarcoma of liver treated with cyclophosphamide, doxorubicin, vincristine, and prednisone regimen and surgery. J Clin Oncol. 2011; 29(35):e849-e851.

10. Arber DA, Weiss LM, Chang KL. Detection of Epstein-Barr Virus in inflammatory pseudotumor. Semin Diagn Pathol. 1998;15(2): 155-160.

11. Shia J, Chen W, Tang LH, et al. Extranodal follicular dendritic cell sarcoma: clinical, pathologic, and histogenetic characteristics of an underrecognized disease entity. Virchows Arch. 2006;449(2):148-158.

12. Long-Hua Q, Qin X, Ya-Jia G, et al. Imaging findings of follicular dendritic cell sarcoma: report of four cases. Korean J Radiol. 2011;12(1): $122-128$.

13. Wang $\mathrm{H}, \mathrm{Su} \mathrm{Z}, \mathrm{Hu} \mathrm{Z}$, et al. Follicular dendritic cell sarcoma: a report of six cases and a review of the Chinese literature. Diagn Pathol. 2010; $5(1): 1-6$. 
14. Mondal SK, Bera H, Bhattacharya B, et al. Follicular dendritic cell sarcoma of the tonsil. Natl J Maxillofac Surg. 2012;3(1):62.

15. Kairouz S, Hashash J, Kabbara W, et al. Dendritic cell neoplasms: an overview. Am J Hematol. 2007;82(10):924-928.

16. Azim HA, Elsedewy E, Azim Jr HA. Imatinib in the treatment of follicular dendritic sarcoma: a case report and review of literature. Oncol Res Treat. 2007;30(7):381-384.

17. Meijs M, Mekkes J, Van Noesel C, et al. Paraneoplastic pemphigus associated with follicular dendritic cell sarcoma without Castleman's disease; treatment with rituximab. Int J Dermatol. 2008;47(6): 632-634.

18. Jiang L, Admirand JH, Moran C, et al. Mediastinal follicular dendritic cell sarcoma involving bone marrow: a case report and review of the literature. Ann Diagn Pathol. 2006;10(6):357-362.

19. Jiang $\mathrm{L}$, Tan H, Wang W, et al. A rare case of follicular dendritic cell sarcoma involving multiple bones. Clin Nucl Med. 2013;38(7):582-585.
20. Jing L, Rui Z, Zhenglong Z, et al. A rare case of recurrent follicular dendritic cell sarcoma. Chin J Pathot. 2010;39(10):709-710.

21. Dong A, Wang Y, Zuo C. FDG PET/CT in follicular dendritic cell sarcoma with extensive peritoneal involvement. Clin Nucl Med. 2014; 39(6):534-536.

22. Li CF, Chuang SS, Lin CN. A 70-year-old man with multiple intraabdominal masses and liver and spleen metastases. Intra-abdominal follicular dendritic cell sarcoma with liver and spleen metastases. Arch Pathol Lab Med. 2005;129(5):e130.

23. Liberale G, Keriakos K, Azerad MA, et al. Intraperitoneal follicular dendritic cell sarcoma: role of chemotherapy and bone marrow allotransplantation in locally advanced disease? Clin Med Insights Oncol. 2015; 9:9-13.

24. Perez-Ordonez B, Erlandson RA, Rosai J. Follicular dendritic cell tumor: report of 13 additional cases of a distinctive entity. Am J Surg Pathol. 1996;20(8):944-955.
OncoTargets and Therapy

\section{Publish your work in this journal}

OncoTargets and Therapy is an international, peer-reviewed, open access journal focusing on the pathological basis of all cancers, potential targets for therapy and treatment protocols employed to improve the management of cancer patients. The journal also focuses on the impact of management programs and new therapeutic agents and protocols on

\section{Dovepress}

patient perspectives such as quality of life, adherence and satisfaction The manuscript management system is completely online and includes a very quick and fair peer-review system, which is all easy to use. Visit http://www.dovepress.com/testimonials.php to read real quotes from published authors. 